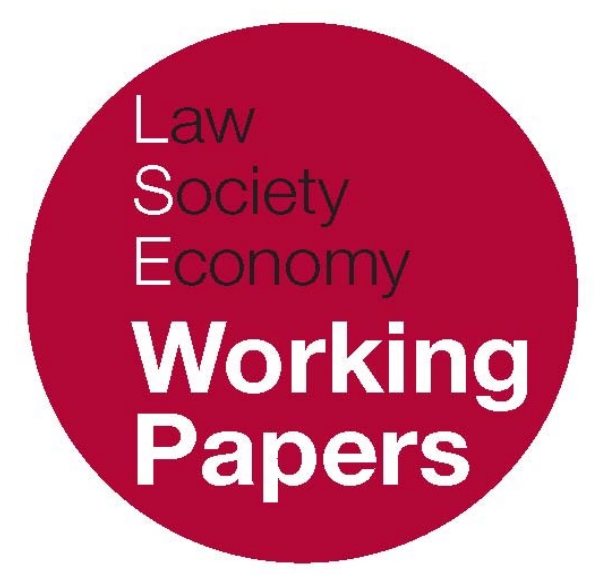

\title{
The Transnationalisation of Law: Rethinking Law through Transnational Environmental Regulation
}

\author{
Veerle Heyvaert
}

LSE Law, Society and Economy Working Papers 04/2016

London School of Economics and Political Science

Law Department

This paper can be downloaded without charge from LSE Law, Society and Economy Working Papers at: www.lse.ac.uk/collections/law/wps/wps.htm and the Social Sciences Research Network electronic library at: http://ssrn.com/abstract $=2745393$.

(C) Veerle Heyvaert. Users may download and/or print one copy to facilitate their private study or for non-commercial research. Users may not engage in further distribution of this material or use it for any profit-making activities or any other form of commercial gain. 


\title{
The Transnationalisation of Law: Rethinking Law through Transnational Environmental Regulation
}

\author{
Veerle Heyvaert
}

\begin{abstract}
This working paper argues that the rise of transnational regulation has a transformative impact on law. It examines the field of transnational environmental regulation to show that its proliferation challenges the continued appropriateness of representations of law as: (i) territorial, (ii) emanating from the state, (iii) composed of a public and private sphere, (iv) constitutive and regulatory in function, and (v) cohesive and regimented. Instead, law is increasingly perceived as (i) delocalised, (ii) flowing from a plurality of sources, (iii) organisationally inchoate, (iv) reflexive and coordinating in function, and (v) polycentric. Together, these shifts in perception amount to a transformation that the paper identifies as the transnationalisation of law. The paper then explores three responses to the transnationalisation of law. It distinguishes responses motivated by a desire to reclaim the traditional conception of law from those that seek to reconstruct law at the transnational level and, thirdly, responses that advocate a context-responsive reconceptualisation of law. Each response, it will be shown, creates a different set of opportunities for and challenges to the relevance of law for transnational regulation.
\end{abstract}

\footnotetext{
* Department of Law, London School of Economics and Political Science. I wish to thank Greg Shaffer for comments on this draft.
} 


\section{INTRODUCTION}

Transnational environmental regulation problematises many conventions about the nature and role of law. This paper identifies five dominant perspectives that have shaped our thinking about law and its relation to society. It explains how the rise of transnational regulation challenges each of these perspectives and invites alternative modes of understanding law. I refer to this process of problematisation, contestation and reform as the 'transnationalisation of law'. The paper first examines the drivers and focal points of change. It then continues to canvas a range of potential responses to the transnationalisation of law and highlight significant strengths and weaknesses of each response. In so doing, this paper provides a critical frame of reference through which to analyse the burgeoning body of procedural and substantive norms that are increasingly treated as constituent parts of an emergent field of transnational environmental law.

\section{TRANSNATIONAL ENVIRONMENTAL REGULATION AND THE CHALLENGE TO LAW}

Transnational environmental regulatory initiatives cause legal complexity. Consider, for instance, the intricate legal and regulatory context in which the Covenant of Mayors operates. The Covenant is a climate change initiative to which many of Europe's major cities voluntarily subscribe. It is administered by the Covenant of Mayors Office (COMO), which is established and funded by the European Commission. Participating towns and cities must develop a baseline emission inventory and are required to submit a Sustainable Energy Action Plan (SEAP), which maps out the different approaches and policies that they intend to implement to achieve the minimum 20\% CO2 emission reduction target. Additionally, participating towns and cities are expected to submit regular implementation reports. ${ }^{1}$ Failure to meet the membership criteria can negatively impact on a city's access to the funding opportunities created within the framework of the Covenant, and may result in their membership being suspended.

Which legal regime governs the relation between the Commission, the COMO and the signatory towns and cities? The answer is supremely challenging. The official text of the Covenant gives no indication as to applicable law; ${ }^{2}$ nor does the adhesion form that town and city councils are requested to sign as a confirmation of their intent to join. ${ }^{3}$ Should such determination need to be made, several jurisdictions

1 V. Heyvaert, 'What's in a Name? The Covenant of Mayors as Transnational Environmental Regulation' (2013) 22:1 Review of European, Comparative and International Environmental Law, pp. 78-90, at 81.

2 http://www.eumayors.eu/IMG/pdf/covenantofmayors text_en.pdf

3 http://www.eumayors.eu/support/library_en.html. 
could credibly vie for the spot. At the very least, a claim could be made for the relations between Covenant parties to be governed by European Union law, or Belgian law (the law of the jurisdiction in which the European Commission and the COMO are located), or the law of the country in which the town or city concerned is located. Either choice creates different advantages and limitations. A choice for EU law would reflect the relevance of both EU institutions in the scheme and of EU legal commitments as the key reference points to determine the minimum aspirations that Covenant members agree to embrace in the fight against climate change. On the other hand, it would arguably defeat the deliberate establishment of the Covenant outside the institutional apparatus of the EU. It might be seen to favour EU-based participating cities over participants from outside the European Union, and it would subject the Covenant to a relatively thin legal regime that has limited experience in both judicial review and adjudicating contractual relationships. This may not be the best choice for the governance of such complex, multi-partite relationships.

Alternatively, the Brussels location of both the European Commission and the Covenant of Mayors Office point towards Belgian law. This choice shares with the previous one the advantage of consistency in that all relations under the Covenant would be reviewed against the same legal standards, without suffering from the relative paucity of experience that characterises EU law. On the other hand, the choice is highly formalistic and could produce inefficient, artificial and potentially unfair results. The prospect that, say, a disagreement between an Italian funding body and an Italian town or city would be shoehorned into the Belgian jurisdiction purely because the facilitating bodies are formally established there, is unattractive. This is all the more so since the connection between these facilitating bodies and the Belgian state is, itself, tenuous. Yet reverting to the law of the country in which the parties involved in the proceedings are located, would lead to both legal fragmentation and considerable complexity, as various authorities in different countries could stamp their own, disparate interpretations on the legal arrangements under the Covenant and the ensuing rights and responsibilities.

The choice of law challenges represented by the Covenant extend beyond the determination of the governing regime, and include the identification of the appropriate legal discipline. It is by no means clear whether any conflict between, for instance, the COMO and a signatory city regarding the former's decision to suspend membership rights is contractual, administrative, or even tort-based in nature. If the Covenant is treated as a regulatory regime, the first option seems appropriate. However, the voluntary nature of membership, with no overt scope for punishment beyond exclusion from the club for non-adherence to club rules, makes the case for contract law. From a formalistic angle, the unilateral commitment structure of the Covenant might argue in favour of treating any disagreements between parties as being of a private but non-contractual nature.

These reflections convey a first impression of the destabilising impact of transnational regulatory activity on assumptions about legal governance. But the examples still underplay the essentially disruptive impact of transnational 
environmental law (TER) on the very concept and content of law. Law, in the preceding example, is talked of as the pre-existing governance regime under which the Covenant resorts. The latter is portrayed, for all intents and purposes, as the passive subject that undergoes law and adjudication. Yet if we embrace the notion that the Covenant produces behaviour that is at least in part regulatory, then the normative content actively developed through Covenant processes may, itself, be a source of law. The Convention does not merely operate in an intricate legal context; it creates an intricate legal context. ${ }^{4}$ Transnational, decentred regulation thus coproduces transnational, decentred law. Moreover, this transnationalisation of law calls into question the usefulness of many of the attributes that conventionally serve to distinguish law from non-law. ${ }^{5}$

\section{MAPPING THE IMPACTS OF TRANSNATIONAL ENVIRONEMENTAL REGULATION ON THE CONVENTIONAL ATTRIBUTES OF LAW}

The following sections offer a framework for organising and discussing the transnationalisation of law. It is argued that to understand the breadth and richness of reactions to the rise of TER, account must be taken of its impact on conventions regarding the location, the sources, the organisation, the functions, and the structure of law. The framework enables us to map the range of challenges to law encapsulated in the emergence of transnational regulation. This, in turn, fosters appreciation of the different and often divergent reactions to the transnationalisation of law, which are reviewed in the third part of this paper.

\begin{tabular}{|l|l|l|}
\hline & Conventional Context & Transnational Context \\
\hline Location & Territorial & De-Localised \\
\hline Source & $\begin{array}{l}\text { Based in or derived from } \\
\text { the state }\end{array}$ & Plural \\
\hline Organisation & Public and Private Law & Inchoate \\
\hline Functions & $\begin{array}{l}\text { Constitutive, Regulatory, } \\
\text { Communicative }\end{array}$ & $\begin{array}{l}\text { Cognitive, Reflexive, } \\
\text { Coordinative }\end{array}$ \\
\hline Structure & Cohesive and regimented & Polycentric \\
\hline
\end{tabular}

${ }^{4}$ Cf. Roger Cotterrell, 'What is Transnational Law' (2012) Vol 37(2) Law \& Social Inquiry, p. 515; KarlHeinz Ladeur, 'The Evolution of General Administrative Law and the Emergence of Postmodern Administrative Law' (March 21, 2011). Osgoode CLPE Research Paper No. 16/2011. Available at SSRN:http://ssrn.com/abstract=1792062 or http://dx.doi.org/10.2139/ssrn.1792062, p. 3, 8.

${ }^{5}$ Cf. Cotterrell, n. 4 above, pp. 512 \& 515; Peer Zumbansen, 'Transnational Private Regulatory Governance: Ambiguities of Public Authority and Private Power' 76 Law \& Contemp. Probs. (2013) pp. 118, 130-131. 


\subsection{LOCATION: TRANSNATIONAL ENVIRONMENTAL REgUlation AND THE 'END OF GEOGRAPHY'}

Law is an intensely territorial concept. Laws emanate from the city, the state, the empire, and hold sway within - and only within — the geographical zone that falls under the governing bodies' control, a zone bordered by physical and frequently contested frontiers. The intimacy of the bond between government, territory, and law resonates in the notion of 'jurisdiction,' which means both the official power to make legal decisions and judgements, and the territory over which legal authority extends. The exclusivity of the relationship is encapsulated in our understanding of legal sovereignty, which represents the entitlement to legal autonomy and selfdetermination and 'rests fundamentally on the notion of exclusive authority over discrete parcels of territory'. ${ }^{6}$ Indeed, the very notion of independent statehood signifies a successful claim to a connection between a governance regime, a physical territory and its population. This connection conveys the entitlement to militarily defend the territory, to levy taxes within the territory, to issue laws for the territory, and enter into international agreements on behalf of the territory. ${ }^{7}$

The rise of transnational regulation threatens the bond between law and geography in two ways. First, it is difficult to locate transnational actors in a particular jurisdiction; they do not have a 'seat' of authority in the way that state regulators do. Secondly, there is no clearly demarcated field of application of the normative content they produce. For private environmental standard setters, for example, the size of their field of application depends entirely on the successful uptake of the standards.

The challenges that TER poses to law and geography are particularly pressing with regard to transnational regulatory activity that takes place outside the auspices of a pre-established supra- or international legal framework. Unless they restrict their membership and field of action explicitly to a single state, private environmental regulators are genuinely and doubly de-localised. As illustrated in the Covenant of Mayors example, there is no obvious candidate jurisdiction in which to ground (quasi) regulatory behaviour that occurs in a transnational network. Often, there will be no legal discipline that can claim undisputed governance over the relations that unfold within the network. ${ }^{8}$ Secondly, the normative content that is generated through the transnational network is, itself, de-localised. The Forest Stewardship Council (FSC) does not create American, Japanese or French sustainable forestry standards; it produces FSC sustainable forestry standards. If the FSC standards are accepted as transnational law, ${ }^{9}$ then this is indeed law that has sprung up in the absence of claims to territory and sovereignty.

\footnotetext{
${ }^{6}$ See Daniel Bethlehem, 'The End of Geography: The Changing Nature of the International System and the Challenge to International Law' (2014) Vol 25(1) European Journal of International Law, p. 13.

${ }^{7}$ Ibid, pp. 13-14.

8 Cf. Joost Pauwelyn, Ramses A. Wessel \& Jan Wouters, Informal International Lawmaking (2012, OUP), at p. 2. ${ }^{9}$ Ibid.
} 
Transnational regulation developed in implementation of regional or international legal frameworks, such as pollutant emission limit values adopted under the EU Industrial Emissions Directive ${ }^{10}$ or decisions to include further species in the endangered lists annexed to the CITES Convention, ${ }^{11}$ are comparatively less problematic. The geographical realm of application of such regional and international regulatory measures formally corresponds to the territory of the signatory states, which functions as an expanded field of jurisdiction. Nevertheless, in this context, too, challenges arise. They are perhaps less acute than those created by the rise of private transnational regulation, but they are certainly not negligible. In the EU, tensions arise because of perennial need to mediate competing claims to territorial exclusivity. At the international level, in turn, the relevance of territoriality is significantly eroded by the growing complexity of international decision making and the dearth of international administrative law. The following paragraphs explain each point in turn.

Preliminarily, it should be noted that the field of application of EU regulation, including particularly its environmental product standards, arguably transcends EU jurisdiction. Like political power, regulatory influence does not stop at the border. We see a recent iteration of this awareness in Anu Bradford's 'Brussels effect', which discusses the extra-jurisdictional 'pull' of legal regimes such as the EU's internal market regulations. Companies that seek access to the affluent EU market must conform to the EU's environmental product standards, wherever they are located. ${ }^{12}$ Hence it could be claimed that, in the EU context too, the connection between regulation and jurisdiction has weakened. This argument is, however, not entirely persuasive. First, extraterritorial regulatory influence is a function of the size and desirability of the home jurisdiction as a market; not of its transnational character. Moreover, regulatory influence does not fundamentally call into question the relevance of territorial jurisdiction. If anything, it could be seen as reinforcing the importance of geography. It is only because the EU can claim legal sovereignty over the EU's territory in matters of product regulation and close off the borders to noncomplying products that the impetus to conform outside the geographical boundaries of the jurisdiction arises.

If the external influence of EU law strengthens rather than weakens the connection between law and territory, EU law's many, often fraught primacy tussles with the Member States are of a more unravelling nature. Internally, the growth of a level of legal authority that geographically overlaps that of the Member States has put enormous pressure on domestic conceptions of the relation between law,

${ }^{10}$ Directive 2010/75/EU on industrial emissions (integrated pollution prevention and control) [2010] OJ L334/17.

11 Convention on International Trade in Endangered Species of 29 Wild Fauna and Flora (CITES), Washington, DC (US), 3 Mar. 1973, in force 1 July 1975, available at: https://www.cites.org/eng/disc/text.php.

12 This is only one, though important, component of the factors producing the Brussels effect. For a full discussion, see Anu Bradford, 'The Brussels Effect' (2012) Vol 107(1) Northwesten University School of Law, p. 1. 
territory and sovereignty. ${ }^{13}$ Many of the landmark European constitutional cases of the past decade reflect, precisely, a preoccupation to reconceptualise or reclaim sovereignty over the national 'parcel of territory' in the face of competing claims from a centralised, de-localised legal authority. ${ }^{14}$ In the EU context, the rise of transnational regulation has not resulted in the absence of geography but has coproduced competing claims to territorial sovereignty that, from a different vantage point but equally urgently, call for a reconsideration of traditional assumptions regarding the relation between law and geography.

Regulatory measures adopted under the auspices of international treaties put relatively less pressure on domestic claims to territorial sovereignty because their authority is typically contingent on ex-post state validation. Yet at the international level, too, the bond between law and geography is increasingly strained. A first contributing factor to de-localisation is the growing institutional complexity of international regulatory and administrative decision making. Consider, for example, the approval of Clean Development (CDM) projects under Article 12 of the Kyoto Protocol. For such approval to come about, at least three different entities need to make affirmative decisions: the Designated National Authority (DNA), which approves the participant's project proposal and forwards the project for validation; the Designated Operational Entity (DOE), a private third-party certifier that validates the project, and the CDM Executive Board (CDM EB), which registers and thereby formally accepts a validated project as a CDM project activity. ${ }^{15}$ Given the geographical spread of DNAs, DOEs and the CDM EB, it is difficult to anchor the set of decisions that culminates in CDM approval within a particular jurisdiction. A potential determination that, ultimately, the decision is taken in furtherance of the Kyoto Protocol and that, therefore, its jurisdiction corresponds to the combined territory of the signatory states, does not offer a genuine resolution. First, the international regime itself provides few administrative principles and standards that could be marshalled to govern CDM decision making. Resorting to the administrative law bodies of the signatory states instead is equally problematic, because these bodies differ from state to state. Hence, CDM decisions are floating entities: they are disconnected from the national level without having been adequately relocated in the international sphere.

In sum, the intensity and precise nature of the challenge differ, but all main variants of TER cause a degree of de-localisation of law.

\footnotetext{
${ }^{13} \mathrm{C}$. Thornhill, 'National sovereignty and the constitution of transnational law: a sociological approach to a classical antinomy' (2013) 3(4) Transnational Legal Theory, pp. 394-460, at. 406; A. van Bogdandy \& S. Schill, 'Overcoming Absolute Primacy: Respect for National Identity under the Lisbon Treaty' (2011) 48 Common Market Law Review 1417; N. Krisch, 'Who is Afraid of Radical Pluralism? Legal Order and Political Stability in the Postnational Space' (2011) 24(4) Ratio Juris, pp. 386-412 at 407.

142 BVerfGE 2/08 Treaty of Lisbon, Judgment of 30 June 2009 (German Constitutional Court); BVerfGE 37, 2712 BvL 52/71 (Solange I-Beschluß); K 32/09 Treaty of Lisbon, Judgment of 24 September 2010) Polish Constitutional Court)' Pl. US 5/12: Slovak Pensions, Judgment of 31 January 2012 (Czech Constitutional Court).

${ }^{15}$ M. J. Kang \& J. Park, 'Analysis of the Partnership Network in the Clean Development Mechanism' (2013) 52 Energy Policy, p. 543.
} 


\subsection{Source: Transnational Environmental Regulation and the Triple Challenge to the State}

Stronger even than the link with physical territory is the connection between law and the concept of the state. The 19th and $20^{\text {th }}$ centuries, in equal parts celebrated and denounced as the heyday of the nation state, witnessed the consolidation of the trinity of state government, legislature and judiciary as a dominant, even exclusive source of law. In the third millennium, in contrast, the exclusivity - even, the dominance - of the state as source of law is under threat. ${ }^{16}$

The proliferation after World War II of public international law in policy fields outside the traditional zones of international relations, including environmental protection, introduced a greater degree of diversity in recognised sources of law. However, this development did not yet genuinely call into question the centrality of the state because international legal authority is understood as derived from state authority. ${ }^{17}$ States sign up to international agreements. States agree to recognise the competence of international courts and tribunals. State law and practice are the key benchmarks for the recognition of customary international law. Instead of constituting a threat, public international law validates of the state as the inescapable, original source of law.

The arrival of EU law as a source of law, on the other hand, heralds a more challenging proposition. The extent to which the exercise of legal authority at the EU level is reducible to the (member) state is a topic of endless examination and contestation. This is not the place to discuss the range of positions in this rich and ever evolving debate. It suffices to say that, to many participants in the debate, the representation of EU law as an affirmation of its Member States' prerogative to enter into international binding agreements, which therefore shores up the legal sovereignty of the state, strains the limits of credibility. Arguably, such representation overlooks the role of key players, such as the European Commission and the European Parliament, that are not accountable to the state. ${ }^{18}$ It ignores the existence of majority voting among Member States. ${ }^{19}$ It does not account for the enormous issue-interdependence and complexity of EU decision making, which easily reduces Member State day-to-day self-determination to a purely theoretical possibility. ${ }^{20}$ To a more significant extent than public international law, EU law

\footnotetext{
16 Thornhill, n. 13 above, p. 406.

${ }^{17}$ C. Brütsch \& D. Lehmkuhl, 'Complex Legalization and the Many Moves to Law' in Brütsch \& Lehmkuhl, Law and Legalization in Transnational Relations (Routledge, 2007), pp. 22-23; J HH Weiler, 'The Geology of International Law - Governance, Democracy and Legitimacy,' (2003) 63 Zeitschrift für ausländisches öffentliches Recht und Völkerrecht, pp. 547-62, at 553-6.

18 A. Ellinas \& E. Suleiman, 'Supranationalism in a Transnational Bureaucracy: The Case of the European Commission' (2011) 49(5) Journal of Common Market Studies, pp. 923-947; E. O. Eriksen \& J. E. Fossum (eds) Democracy in the European Union. Integration Through Deliberation (Routledge, 2002), p. 4.

${ }^{19}$ Cf S. C. Sieberson, 'Inching Towards EU Supranationalism? Qualified Majority Voting and Unanimity under the Treaty of Lisbon' (2010) 50(4) Virginia Journal of International Law, 920, pp. 926-932.

${ }^{20}$ R. Kardasheva, 'Package Deals in EU Legislative Politics' (2013) 54(4) American Journal of Political Science, pp. 858-874.
} 
worries at the fabric of state-centred conceptualisations of law and legality. Its existence calls into question those classical iterations of the rule of recognition that inexorably lead back to the constitutional authority of the state.

The proliferation of transnational regulation intensifies this challenge in several ways. First, the provenance of the rules that are deemed to govern much of transnational regulatory activity is unclear. This is definitely the case for private transnational regulation, which typically has no obviously identifiable 'home jurisdiction'. But it is also the case for transnational regulation under the auspices of international legal instruments, because neither these instruments nor public international law are rich on legal provisions that are, essentially, administrative in nature. It is therefore not surprising that discussions on the legality and legitimacy of transnational environmental regulation, for example, often refer to abstract notions of, e.g., accountability or transparency without clarifying which legal regime's rendition of accountability or transparency is targeted. ${ }^{21}$ They seemingly operate on the assumed existence of an inchoate, common conception of the meaning of administrative standards, but it is rarely made explicit where this common conception comes from and what it consists of. ${ }^{22}$ Karl-Heinz Ladeur recognises and advocates the development of an experimental, inductive approach to the production of a new administrative legality: 'Particular emphasis should be placed on the question of the 'sources' of the emerging regulatory order. Arguably, the new relational 'rationality of networks' can no longer be regarded as being 'deposited' in a canonical (legal) text; instead, legal meaning must be generated from several overlapping texts and contexts of practice in an experimental approach that comprises both the domestic and the transnational realms'. ${ }^{23}$

Secondly, transnational regulation may, itself, be considered as a source of law, one that is emphatically not traceable to the state. The legal content produced by transnational environmental regulators does not just problematise the state's dominance as a source of law (as EU law does), it raises the possibility of law in the very absence of the state. Roger Cotterrell speaks of a paradigm shift: 'One might think of transnational networks of community as the ultimate source of their own legal regulation but, equally, as being subject to legal regulation created in other such networks that impinge on them (...) So it is possible to envisage a kind of paradigm shift in legal inquiry provoked in part by the development of transnational law: a shift away from a limited nation-state focus and toward a new emphasis on the lawcreating potential of complex, interpenetrating networks of social relationships of community'. 24

21 See, e,g., R. Glicksman \& T. Kaime, 'A Comparative Analysis of Accountability Mechanisms for Ecosystem Services Markets in in the United States and the European Union' (2013) 2(2) Transnational Environmental Law, pp. 259-283.

22 See B. Kingsbury, N. Krisch \& R. B. Stewart, 'The Emergence of Global Administrative Law' (2005) 68(3/4), Law and Contemporary Problems, pp. 15-61, at 29-31 (on the difficulty of identifying the source(s) of global administrative law).

${ }^{23}$ Ladeur, n. 4 above, p. 249.

${ }^{24}$ Cotterell, n. 4 above, p. 515. 
Both as author and subject, TER calls into question the assumption that the construction of law is the privilege of a single actor (the state) or, at most, a select few. ${ }^{25}$ It even calls into question the long established function of the source of law as a rule of recognition. Indeed, if we take TER seriously as a source of law, the question arises whether legal authorship is genuinely knowable and attributable. In the multi-directional and reflexive environment of transnational regulatory networks, the distinction between regulator and regulatee fades. ${ }^{26}$ In a Habermasian sense, it could be argued that TER blurs the distinction between strategic action and communicative action. ${ }^{27}$ With it, opportunities to designate with conviction those nodes within the network that constitute the source of law, recede. TER thus erodes the conceptual walls protecting formal representations of law and regulation representations that thrive on binary distinctions between regulator and regulatee, law maker and legal subject, legality and illegality — and uncompromisingly confronts us with the much messier, reflexive reality in which law is being made and experienced through the countless interactions of ever permutating groups and networks.

\subsection{Organisation: Transnational Environmental Regulation and THE Dissolution OF Disciplinary Divides}

Possibly the most tangible pressure that transnationalisation exerts on the legal system is exercised through the problematisation of public/private disciplinary divides. ${ }^{28}$ This is largely a consequence of private and hybrid actors stepping into roles that are traditionally associated with public authority.

A significant proportion of transnational environmental governance initiatives are elective. Membership is voluntary. Non-compliance with relevant standards and practices is not necessarily actively policed or, should it be, may not entail punitive consequences beyond the suspension or withdrawal of membership status. Yet the compliance pull that radiates from these programmes often belies their modest formal status. ${ }^{29}$ In fact, their real but informal authority, and the means it creates to ensure the programme's effectiveness without resorting to the apparatuses of administrative and criminal law, are one of the key benchmarks to distinguish regulatory initiatives from other, non-regulatory governance structures. ${ }^{30}$

The regulatory or near-regulatory character of transnational environmental initiatives provokes by now familiar questions of legal governance: should the legality of the interactions within the group or network be judged by public or

\footnotetext{
25 Thornhill, n. 13 above, p. 406.

26 Brütsch \& Lehmkuhl, n. 17 above, p. 23.

27 Jürgen Habermas, Theorie des kommuikativen Handlens (Frankfurt am Main; Surhkamp, 1981).

${ }^{28}$ Cf. S. Cassese, 'Administrative Law without the State? The Challenge of Global Regulation' (2005) 37

NYU Journal of International Law \& Politics, pp. 663-694, at pp. 669 and 679.

29 P. Berman, Global Legal Pluralism. A Jurisprudence of Law beyond Borders (CUP, 2014), p. 56.

${ }^{30}$ Heyvaert, n. 1 above, p. 83
} 
private law standards? The question is deeply relevant for the day to day organisation and conduct of TER since private, contractual behaviour is judged against considerably different yardsticks from those used for public, administrative behaviour. ${ }^{31}$ Transparency and openness, for example, are keystone virtues in public law. In a private, contractual setting, the qualities of exclusivity and confidentiality often take precedence. Moreover, as in matters concerning location and source, the ambiguity of TER problematises both the determination of the legal system to which regulatory behaviour ought to be subjected, and the disciplinary affiliation of the legal content it produces. The potential ramifications of classifying, say, a conservation contract as a public act or a private contract are hugely significant, particularly when it comes to determining the rights and responsibilities of third parties. In a public law sphere, interested outsiders would have greater opportunities for involvement in the decision making process and for judicial review. In the private sphere, third party rights derived from contract are virtually non-existent. On the other hand, any external negative impact from the conservation contract may be more easily vindicated if the contract is considered a private arrangement than if it is treated as an administrative decision in the pursuit of the public interest.

The position of much of transnational environmental activity at the crossroads of public and private law presents a taxing intellectual puzzle. Yet the challenges run deeper: it calls into question the very usefulness of organising the discipline of law into demarcated public and private spheres. Pioneering case studies such as Natasha Affolder's work on transnational conservation contracts, and Benjamin Richardson's exploration of tensions between fiduciary and environmental law prescriptions in the field of socially responsible investing (SRI), suggest that it is not a question of ascertaining the 'right' sphere in which to house TER; neither private nor public law can autonomously deliver the regulating and legitimising qualities that are necessary for such conservation contracts or responsible investment practices to flourish. ${ }^{32}$

In the transnational regulatory sphere, the walls that separate public and private law may therefore lose both their resilience and their usefulness. Their crumbling can be read as another tell-tale symptom of the weakening bond between state, territory and law. ${ }^{33}$ The affirmation of private law is, after all, an exercise of public authority. Such affirmation may be highly explicit, as in the strategic enactment of civil law codes in the Napoleonic era. ${ }^{34}$ It might also be residually established through the legal construction of public institutions with clearly and exhaustively designated competencies, privileges and responsibilities. This fences off newly established bastions of public authority and lifts them out of the mass of private

31 Cf. Zumbansen, n. 5 above, p. 120.

32 Natasha Affolder, 'Transnational Conservation Contracts' (2012) Leiden Journal of International Law, pp. 443-460; Benjamin J. Richardson, 'Socially Responsible Investing for Sustainability: Overcoming Its Incomplete and Conflicting Rationales’ (2013) Vol 2(2) Transnational Environmental Law, pp. 311-338.

33 Cf Thornhill, n. 13 above, p. 406.

34 J.-L. Halpérin, 'L'Histoire de la Fabrication du Code le Code: Napoléon', Pouvoirs 2003/4(107), 11-21. 
entanglements fomented from human interaction. Transnational environmental regulation questions both the sturdiness and the relevance of the fence.

\subsection{FunCtion: Transnational ENVIRONMENTAL REgUlation and the ENHANCED REFLEXIVITY OF LAW}

Transnationalisation has re-energised debates regarding the role of law in global society. Preliminarily, it should be acknowledged that to talk of 'the role of law' and the impact of TER on the role of law suggests that, outside the context of transnational regulation, the role of law is a singular, universally understood and agreed upon concept. Centuries of heated jurisprudential exchange attest that this is certainly not the case. Viewpoints abound about what role — or, what combination of roles - law fulfils for society, about the relation and ranking between different roles, and the desirability to enhance or suppress particular functionalities. The point is, rather, that the emergence of transnational regulation, and TER in particular, suits some accounts of what law does for society, but problematises others. TER thus productively destabilises the debate and creates a new agenda both for those who see their account of the role of law affirmed by the rise of TER, and those who see law's functions as frustrated by transnational regulatory activity.

This examination of the impact of TER on the functions of law starts from a familiar place, namely, the mainstream account of the role of law as constitutive of regulatory and administrative authority. ${ }^{35}$ Law sets the terms for the institutionalisation of power and thereby enables the very establishment of regulatory and administrative institutions. The 1995 UK Environment Act, which opens with the lofty words 'There shall be a body corporate to be known as the Environment Agency'; the provisions mapping out the composition and competencies of the European Commission, the Council, and the European Parliament in the Treaty of the European Union (TEU), ${ }^{36}$ and any international convention article entitled 'Conference of the Parties,' embody the constitutive function and force of law. The latter two examples simultaneously affirm that the constitutive role of law does not disappear beyond the level of the state. However, it is severely impacted. ${ }^{37}$ For every transnational environmental regulator that operates under the auspices of exogenous, binding terms of reference, there is a counterexample that does not. Private and hybrid regulators such as the Marine Stewardship Council (MSC) and the International Organization for Standardization (ISO), and transnational networks such as the Covenant of Mayors, all organise without the constitutive pneuma of law.

\footnotetext{
35 Ming-Sung Kuo, 'From Administrative Law of Administrative Legitimation? Transnational Administrative Law and the Process of European Integration' (2012) 61(4) International \& Comparative Law Quarterly, p. 863.

36 Leviathan, ch. 26, at 189 (R. Tuck (ed.), 1996.).

37 Thornhill, n. 13 above, pp. 403-404.
} 
TER equally puts severe pressure on the regulating functions of law. This refers to law's role as a meta-regulator; a supplier of procedural and substantive norms that constitute a framework capable of structuring, supervising and disciplining the conduct of regulation. ${ }^{38}$ This function is typically associated with administrative law. It is readily apparent that the triple impacts of de-localisation, institutional decentring and the blurring of disciplinary boundaries limit opportunities for administrative law to fulfil the functions of structuring, supervising and disciplining regulatory behaviour. With the possible exception of EU administrative law, supranational administrative legal regimes are normatively thin and disconnected from the institutional enforcement apparatus that is vital to enhancing the effectiveness of the structuring and disciplining influence of administrative law. As the roster of transnational regulators expands, the perceived deficit of administrative law to govern their conduct becomes ever more acute. ${ }^{39}$

The erosion of the constitutive and regulatory functions of law vis-à-vis transnational regulation can also impede law's communicative function. ${ }^{40}$ Law is a vital channel through which governments and courts publicise their vision of what constitutes good regulation and administration. A dearth in constitutive and administrative law reduces opportunities for interpellation, debate and, consequently, government accountability.

From this vantage point, TER has a profound and potentially crippling impact on law's functionality. However, not everyone subscribes to the idea of law as conceptually and operationally separate from that which it professedly governs. According to Ladeur, the constitutive role of law as an external organising principle that beams down on regulatory and administrative behaviour has always been an illusion: 'The fundamental forms and components of general administrative law have not been developed by the legislator nor by the judiciary (which has made some of its implicit rules explicit) but by an experimental search process of the administration itself. ${ }^{41}$ This account represents a more self-generating and organic understanding of law; one in which the role of law is not to create normative content but to reflect rules and standards as they emerge and consolidate within the day-today reality of regulatory and administrative decision making. Law is not superimposed on the regulatory and administrative life world, it is produced and reabsorbed within the very processes and practices that it codifies. It is, in Lon Fuller's words, a 'language of interaction'. ${ }^{42}$

If law is a co-product rather than an originator of decision making, then our expectations of its autonomous constitutive and disciplining power have been overstated. At most, law can contribute to the 'stabilization of normative

${ }^{38}$ Cf C. Anderson, 'Contrasting Models of EU Administration in Judicial Review of Risk Regulation' (2014) 51 Common Market Law Review, p. 425; A. Alemanno, 'The Shaping of European Risk Regulation by Community Courts,' Jean Monnet Working Paper No. 18 (2008), pp. 7-10.

${ }^{39}$ Kuo, n. 35 above, p. 863.

${ }^{40}$ V. Heyvaert, 'Levelling Down, Levelling Up, and Governing Across: Three Responses to Hybridization

in International Law' (2009) 20(3) European Journal of International Law, pp. 647-674, at p. 662.

${ }^{41}$ Ladeur, n. 4 above, p. 5.

42 L.L. Fuller, 'Law and Human Interaction' (1977) 47(3/4) Sociological Inquiry, pp. 59-89, at 61. 
expectations' 43 and foster 'the selection and upholding of such expectations even in the face of disappointment'. ${ }^{44}$ Law is informative rather than formative; law facilitates stable self-ordering rather than impose order.

In the autopoietic/constructivist/interactive perspective associated with the writings of authors such as Luhmann, Teubner, Calliess and Renner, Ladeur, and Fuller, the key functions of law are facilitative and cognitive. The rise of TER changes the way in which law is co-produced, but does not fundamentally threaten its facilitative and cognitive functionality. Evidently, the existing corpus of international, administrative, environmental and contract law does enough to manage uncertainty to an extent that it does not impede the blossoming of manifold transnational environmental regulatory initiatives. Expectations between the participants in governance networks are stable enough for these networks to persist and even thrive. ${ }^{45}$ Simultaneously, a developing body of decision making protocols and standard-setting practice is being documented. Protocols and standards fulfil a vital informative function about what the normative expectations within the transnational regime are. ${ }^{46}$ The information thus created is diverse and differentiated, but it does contribute to an evolving, flexible understanding of the normativity of TER, which then in turn helps to stabilise continuing transnational regulatory and administrative behaviour.

In sum, accounts that position law as a hierarchically superior force external to administration yet capable of shaping its design and operation, are threatened by the rise of transnational regulatory regimes. ${ }^{47}$ The latter seem to exemplify much more aptly law's reflexive potential. To some, the shift in representation from 'law as authority' to 'law as reflection' constitutes a diminishment of the status of law and its role in society. To others, it is instead a closing of the gap between the myth and the reality of law.

\subsection{Structure: Transnational Environmental Regulation and REgIME POLYCENTRICITY}

As it challenges the monopoly of the state as the source of law, so does TER call into question the accuracy of representing the legal system as a hierarchically organised, regimented and fully articulated structure. 48 Concepts such as the 'architecture' of law evoke an image of law as a cohesive, comprehensive system

43 Gralf-Peter Calliess and Moritz Renner, 'Between Law and Social Norms: The Evolution of Global Governance' (2009) 22(2) Ratio Juris, p. 267.

${ }^{44}$ Ibid.

${ }^{45}$ Fuller, n. 42 above, pp. 61-64.

46 On the cognitive function of law, see also F. von Benda-Beckmann and K. von Benda-Beckmann, 'The Dynamics of Change and Continuity in Plural Legal Orders,' (2006) 53(4) Journal of Legal Pluralism \& Unofficial Law, p. 12.

${ }^{47}$ Cf Colin Scott, 'Analysing Regulatory Space: Fragmented Resources and Institutional Design' (2001) Public Law, p. 333.

48 Brütsch \& Lehmkuhl, n. 17 above, pp. 22-23. 
built on solid, singular foundations - national constitutions for domestic law; the EU Treaties for the EU legal regime; the Vienna Convention on the Law of Treaties for international law. 49

The difficulties in determining which sets of laws and rules should govern transnational environmental regulation, illustrated in the example of the Covenant of Mayors, cast a shadow on the assumption of architectural cohesion of the legal edifice. The claims to legal status of the normative content produced through transnational regulatory decision making, are even harder to reconcile with a systematic, pyramidal vision of law. Instead, law unfolds as a network; one with stronger, weaker and even missing links - maybe a patchwork more than a network. ${ }^{50}$ The law that feeds into and emanates from transnational regulatory decision making does not self-organise into a monolithic structure; it is fragmented and polycentric. The normative practices developed and replicated within, for example, ISO standard setting certainly reflect aspects of domestic and regional administrative law regimes that are imported into the proceedings via the expectations and routines of governmental as well as non-governmental ISO members, but they cannot be properly 'housed' within a pre-established organigram of international, regional or national administrative law. Law's structure is perennially inchoate.

\section{RESPONDING TO TRANSNATIONALISATION: RECLAIMING, RECONSTRUCTING OR RECONCEPTUALISING}

Both as subject and source of law, transnational regulation calls into question established assumptions about the key attributes of law. Law is perceived as increasingly de-localised, pluralistic, inchoate, reflexive and polycentric. The preceding discussion also affirms that not every variant of TER exerts an equal amount of pressure. The decisions of transnational environmental standard-setters such as the ISO, which defy easy classification under any legal regime or discipline, present a more acute challenge than those of the European Commission, which are generated through a highly developed, supranational legal regime that replicates many features and functions of domestic law. Yet whether nagging or acute, it would

\footnotetext{
49 Neil Gunningham's work illustrates both the assumption of stability and the extent to which this assumption is under threat in 'Environmental Law, Regulation and Governance: Shifting Architectures' (2009) 21(2) Journal of Environmental Law, pp. 179-212.

50 Benvenisti observes a similar sensibility reflected in recent American writing on international law: 'a view shared by scholars who deny that there is anything "out there" other than solitary treaties floating around in no particular hierarchy in the abyss of international anarchy'. It should, however, be noted that representation is typically used not to challenge the systemic vision of law at a fundamental level, but to buttress claims for a return to the values of state sovereignty and subordination of transnational to national law. See E. Benvenisti, 'The Future of International Law Scholarship in Germany: The Tension Between Interpretation and Change' (2007) 67 Zä̈RV, p. 587.
} 
be desperately short-sighted to ignore the practical and conceptual problems that accompany the rise of TER.

The following pages map out a variety of possible responses to the transnationalisation of law. For the sake of clarity, the material is organised into three distinctive categories, namely, responses that aim to reclaim law as conventionally conceived; those that seek to reconstruct law and thereby restore its conventional attributes and functionalities; and a third group of responses that advocate a reconceptualisation of law that is more in tune with the changes rung in by transnationalisation. ${ }^{51}$ It goes without saying that the full wealth of reactions to the transnationalisation of law, as expressed in regulation, case law and scholarship, does not always allow itself to be neatly stored into one of three mutually exclusive categories. Nor are commentators necessarily aware of whether their suggestions have an essentially defensive, conservative or creative bent. However, a more systematic understanding of the range of possible reactions to transnationalisation, whether expressed in case law, in scholarship or through legislative reform initiatives, strengthens our ability to process, contextualise and critically engage with individual responses.

\subsection{Conservative ANd Defensive: ReClaiming LaW}

The transnationalisation of law unlocks a Pandora's box of conceptual dilemmas, uncertainties and transitional problems. One way to solve the deluge of new challenges is to re-seal the box and reassert the traditional boundaries of law. To this end, the transnationalisation of law is resolutely kept outside the zone of 'law proper'. Defensive responses to transnationalisation seek to keep intact the formal distinction between state-sanctioned public regulation and private regulation, however similar their impact. The barrier between officially promulgated, binding laws that are made effective through national enforcement mechanisms and backed up by punitive sanctions on the one hand, and conventional norms that derive their authority primarily from expertise, persuasion, and widespread voluntary compliance on the other, is strictly maintained.

Consequently, defensive responses relegate the lion's share of TER to the private legal sphere. The standards adopted by, for instance, the FSC are treated as private conventions; the relation between the FSC and its members is a contractual one. Choice of law questions that may arise in a dispute between parties in the FSC

\footnotetext{
${ }^{51}$ For comparison, see Nico Krisch's discussion of 'containment,' 'transfer' and 'break' as three reactions to the democracy challenges represented by the emergence of postnational law. See N. Krisch, Beyond Constitutionalism. The Pluralist Structure of Postnational Law (2010, OUP), pp. 14-22. Krisch's brief analysis focuses chiefly on the different interpretations of the relation between democracy, legitimacy and constitutionalism that underscore the diverse responses. The analysis below, in contrast, focuses its attention on the consequences of embracing one or other viewpoint. See N. Krisch, Beyond Constitutionalism. The Pluralist Structure of Postnational Law (2010, OUP), pp. 14-22. See also Berman's discussion of sovereigntist, universalist and pluralist constructions of the global legal order. P. S. Berman, Global Legal Pluralism. A Jurisprudence of Law Beyond Borders (2014, CUP), p. 14.
} 
network are resolved through conflict of law rules (also known as "private international law') as applied by the dispute settlement body seized of the conflict. Third party ramifications of the contractual standards agreed to by FSC members are legally relevant only to the extent that such standard setting might constitute anti-competitive behaviour.

More nuanced defensive responses to transnationalisation combine the desire to safeguard the formal divisions between law and non-law with an awareness of the de facto similarities between legal and non-legal norms. ${ }^{22}$ This resonates in the popularity of concepts such as 'soft law,' 'quasi-regulation' and 'governance,' which simultaneously underscore the similarity and the otherness of normative dynamics in the transnational field. OECD codes of conduct are like law yet not law; they are 'soft law'. ${ }^{53}$ Transnational cooperation in standard setting for sustainable farming is like regulation but not regulation; it is 'quasi-regulatory'54 or constitutive of 'governance' rather than a regulatory regime. 55 The introduction of a sui generis set of para-legal terminology offers the benefit of locating the transnationalisation of law close enough to the legal sphere to legitimise its colonisation by lawyers, but simultaneously affirms the specialness and authority of the newly constructed 'core' of law and regulation. State-issued law is no longer merely law; it is 'hard law'.

The establishment of a para-legal zone conceptually shelters the core of 'real' law from the challenges triggered by transnationalisation, and stimulates inquiries into the nature and status of this newly established soft-, para- or quasi-legal periphery. Soft law is the subject of a rich vein of scholarship that explores the main reasons why actors resort to non-binding modes of norm setting; the variety of formats in which soft law is encapsulated; and the ways in which soft law has been used alongside or distinguished from hard law by traditional sources of legal authority. ${ }^{56}$ Many writings emphasise soft law's precursor status: it often functions to lower the threshold for agreement and as a stepping stone toward a final, binding legal product. ${ }^{57}$ This is an affirmative account, but it does portray non-traditional legal activity as instrumental and in support of a more enduring, prestigious end goal. The final destiny for successful soft law is elevation to the ranks of real, hard law.

\footnotetext{
${ }^{52}$ Ladeur, n. 4 above, p. 9.

53 M. Marcussen 'OECD Governance Through Soft Law'. in U. Mörth (ed.), Soft law in governance and regulation: an interdisciplinary analysis. (E. Elgar, Cheltenham, 2004), pp. 103-128.

${ }^{54}$ C. Ray, 'Transnational Co-operation Between Rural Areas: Elements of a Political Economy of EU Rural Development' (2001) Vol 43(3), Sociologia Ruralis, pp. 279-295.

55 Cf. L. Kotzé, Global Environmental Governance. Law and Regulation for the 21st Century (2012 Edward Elgar), p. 83.

${ }^{56}$ F. Terpan, 'Soft Law in the European Union - The Changing Nature of EU Law' (2015) 21(1) European Law Journal, 68-96; J. d'Aspremont \& T. Aalberts (eds) 'Symposium on Soft Law' (2012) 25(2) Leiden Journal of International Law, pp. 309-378; Heyvaert, n. 40 above, fn. 3 (overview of key publications on soft law between 1990 and 2009)

57 G. Shaffer, 'Theorizing Transnational Legal Ordering' Annual Review of Law and Social Science (2016, forthcoming); KW Abbott and D Snidal, 'Hard and Soft Law in International Governance' (2000) 54 International Organization 421; G Shaffer and MA Pollack, 'Hard vs. Soft Law: Alternatives, Complements, and Antagonists in International Governance' (2010) 94 Minnesota Law Review 706.
} 


\subsubsection{Advantages and Disadvantages of Reclaiming Law}

Defensive responses to the transnationalisation of law have an obvious appeal. They avoid the disruption that accompanies attempts at reconceptualisation, preserve the relevance of generations of legal knowledge and praxis, and imbue decision making with continuity and, hence, predictability. On the other hand, unwillingness to confront the impacts of transnationalisation widens the gap between 'the law on the books' and 'what really happens' which may dent law's credibility as an effective disciplining force of political power. Moreover, the decision not to engage with the regulatory character of transnational arrangements arguably represents a missed opportunity to lend structure and support to innovative attempts at public interest regulation. Considering the gaping chasm between the scope and pace of 'traditional' climate change regulation and the extent of intervention required to achieve sustainable climate targets, such opportunities may be too costly to miss.

Ultimately, the main shortcoming of boundary drawing exercises is that they tend to ignore or displace rather than truly resolve the tensions caused by transnationalisation. The conceptual clarification that comes from firmly locating, say, the environmental instruments adopted under the 2007 Association of South East Asian Nations (ASEAN) Charter ${ }^{58}$ outside the sphere of real law, does little to alleviate concerns about the transparency and responsiveness with which such measures were adopted. Housing the same instruments into the 'soft law' category does create some space for these issues to be debated, but offers little instruction on how such debates should be settled.

Arguably, the introduction of notions such as soft law, quasi regulation and governance do not so much fix the boundaries between law and non-law as represent an institutional choice about the appropriate forum for determination. The question of exactly what consequences to attach to the label of 'soft law' usually remains suspended until it falls in the lap of judicial and arbitration bodies. 59 The European Court of Justice (ECJ) ruling in Fra.bo exemplifies this. ${ }^{60}$ Here, the ECJ was asked whether the refusal by a German certification body, the Deutsche Vereinigung des Gas- und Wasserfaches eV (DVGW), to recognise the validity of a certificate issued by an Italian certification entity which was not on DVGW's approved list, could be construed as an impediment to the free movement of goods (Article $34 \mathrm{TFEU}$, then $28 \mathrm{EC}$ ). The catch was that DVGW is a private organisation. Under German law, DVGW certification is not essential to prove that construction products (in this case, copper fittings) meet mandatory safety standards, but the DVGW certificate bestows a presumption of conformity. Alternative avenues to

\footnotetext{
${ }^{58}$ Koh Kheng-Lian, 'Transboundary and Global Environmental Issues: The Role of ASEAN’ (2012) 1(1) Transnational Environmental Law, pp. 67-82.

59 See E. Korkea Aho, 'Laws in Progress? Reconceptualizing Accountability Strategies in the Era of Framework Norms' (2013) 2(2) Transnational Environmental Law, pp. 363-385, at 378-384.

${ }^{60}$ Case C-171/11, Fra.bo SpA v Deutsche Vereinigung des Gas- und Wasserfaches eV (DVGW) - TechnischWissenschaftlicher Verein, judgment of 12 July 2012.
} 
prove compliance are underspecified and costly. ${ }^{61}$ In its submission, the DVGW asserted that only the German state was bound by Article 28 EC. Consequently, there was 'nothing preventing the DVGW from drawing up technical standards which go beyond those in place in Member States other than the Federal Republic of Germany and to apply them to its certification activities. It is also free, on qualityrelated grounds, to take account only of laboratories accredited by it'. ${ }^{2}$ The ECJ did not dispute DVGW's status as a private body, but considered that because, first, German legislation provided that goods certified by DVGW would be compliant with national law; secondly, the DVGW was the only body that certified copper fittings in Germany; and, thirdly, a lack of certification by DVGW would result in serious difficulties in placing the product on the market, the DVGW 'in reality (held) the power to regulate'. ${ }^{63}$

Fra.bo relies on a preponderance of the evidence approach to resolve the boundary dispute and situate DVGW's certification activities on the public side of the public/private divide. The case-by-case, solving approach to questions regarding the legal status of non-traditional regulators, which is inherent in judicial determination, imbues the process with a considerable degree of flexibility and scope for fairness in decision making. At the same time however, it is not the most conducive to establishing general criteria regarding the legal status of de facto authoritative bodies. It takes more than one ruling to confidently crystallise generalisable rules. In this manner, too, the institutional choice to settle 'boundary disputes' through (individual) judicial determination instead of through (general) rule making presents itself as a defensive rather than offensive response to the transnationalisation of law.

\subsection{Conservative AND AdAPtive: Reconstructing LAW}

A second cohort of responses to the transnationalisation of law shares with the first that it is essentially conservative: it seeks to alleviate the pressures on conventional understandings of the location, sources, functions, disciplines and structure of law. But in contrast to the first, commentators who espouse conservative and adaptive perspectives display a greater willingness to confront the undesirable consequences of maintaining a strict law/non-law, public/private divide. Such undesirable consequences may manifest in, for example, the inability of contract law to address the lack of transparency with which private transnational regulators behave. Or in the inability to appeal against decisions adopted by transnational environmental regulators, such as the CDM Executive Board. ${ }^{64}$ Following a conservative and adaptive approach, law should be tweaked, adapted and, where necessary, newly produced to bridge the discrepancy between the private form and the public

\footnotetext{
${ }^{61}$ Ibid., at [29].

62 Ibid., at [14].

${ }^{63}$ Ibid., at [31].

${ }^{64}$ C. Streck \& J. Lin, 'Making Markets Work: A Review of CDM Performance and the Need for Reform' (2008) 19(2) European Journal of International Law, pp. 409-442, at 426-428.
} 
substance of transnational regulation. New law should fix the gaps in the fabric of legal protection torn by the emergence of transnational regulators. Conservative and adaptive responses to the transnationalisation of law aim to reconstruct the conventional role and functions of law through the creation of new generations of public transnational law.

Views differ on whether adapting law to the transnational context is a matter of implementing a few discrete fixes, or instead calls for a large-scale overhaul. It has been argued that, in their enthusiasm for the new and challenging, scholars easily overestimate the proportion and weight of transnational regulation. In reality, it is countered, the irritation caused by the transnationalisation of law remains modest, and most of it can be managed with old fashioned legal tools. ${ }^{65}$ Conflict of laws doctrines may not provide perfect answers to problems of dislocation, but they still perform the core task of identifying possible forums and plausible legal regimes under which transnational legal conflicts can be housed. Similarly, in response to the challenges associated with the blurring public/private divide, it is possible to expand the scope of state regulation of the private sector to introduce requirements that specifically address the increasingly regulatory character of private governance. Such requirements may be adopted under the mantle of shareholder protection, consumer protection, or environmental protection. Their main target is to imprint an ethos of good governance on the private sector that is comparable to the expectations of administrative law vis-à-vis public regulators. The official justification of transparency, consultation and review requirements may be the protection of shareholder or consumer interests, but their introduction simultaneously supports the development of a broader concept of responsibility and accountability of (private) transnational regulators.

Thus, the tensions that result from maintaining a formal distinction between public and private regulators are alleviated through the introduction of functional equivalents of public law expectations in the private sphere. ${ }^{66}$ As an example, Kahler refers to the US Sarbanes-Oxley Act (2002), which requires private companies to establish a contract management system. Such systems can reduce the risk of contract failure, but whether it was cost effective to implement them was formerly down to the individual enterprise to decide. The introduction of the contract management requirement as a legal obligation could be viewed as a response to the growing expectation that private as well as public organisations conform to 'best practice' or 'good governance' as a matter of law, in the interest of both their contractual partners and the public at large. ${ }^{67}$

\footnotetext{
${ }^{65}$ Ralf Michaels, for example, has proposed a more inclusive approach to conflicts of law as a way to resolve competing claims between state and non-state law. See R. Michaels, 'The Re-Statement of Non-State Law: The State, Choice of Law, and the Challenge from Global Legal Pluralism' (2005) 51 The Wayne Law Review, pp. 1209-1258, at 1250-1258. Zumbansen, n. 5 above, p. 127. Note that Zumbansen discusses this view in the literature, but does not personally espouse it.

${ }^{66}$ See H. J. Steiner \& D. F. Vagts, Transnational Legal Problems (2d ed. 1976, Foundation Press), p. xvii.

${ }^{67}$ L. Kahler, 'Contract-Management Duties as a New Regulatory Device' (2013) 76 Law \& Contemporary Problems, pp. 89-103, at $90 \& 94$.
} 
Others consider that the disruptive consequences of the transnationalisation of law cannot be countered by mere tweaking, but require more thorough and systematic legal reform efforts. ${ }^{68}$ Natasha Affolder's aforementioned study of transnational conservation contracts leads her to examine the notions of fairness in private (contractual) law and in public (international environmental) law. Her conclusion is that the two notions are not fully reconcilable; in fact, they pull in opposite directions. Fairness in contract law refers to the fairness between the contracting parties, and is typically protected by ensuring the privity of the contractual relations and prioritising contractual interests over external concerns. Fairness in international environmental law, in contrast, is closely bound with notions of transparency and access to the negotiation process. In these circumstances, it is difficult to simply tweak notions of fairness in contract law to reflect the regulatory aspects of transnational conservation contracts without such adaptation effectively constituting a distortion. Correspondingly, Affolder calls for a more advanced response in the development of a transnational legal concept of fairness that 'extends rather than simply recycles fairness thinking in domestic and international law'. ${ }^{69}$ In a similar vein, Benjamin Richardson uncovers fundamental tensions between Socially Responsible Investment (SRI) as a transnational governance regime and fiduciary finance law: 'The seemingly exclusive focus of fiduciary law on the interests of investors, especially their financial interests, potentially clashes with any vision of SRI prioritizing environmental and social responsibility'.70 The reconciliation, he argues, involves adopting both a more productive rationale for SRI and a reconceptualisation of fiduciary law. ${ }^{71}$

In their most expansive expression, conservative and adaptive responses to the transnationalisation of law advocate the establishment of new, encompassing legal frameworks to govern TER. EU administrative law, an initially underdeveloped tenet of EU legal integration that has gradually matured in response to the growing presence and immediacy of EU regulation, ${ }^{72}$ is often advanced as a model for the development of additional regional, or potentially global, regimes of public law. ${ }^{73}$ Alternative conceptions for models of public transnational law include the development of 'an international law of corporate social responsibility'. The idea starts from the premise that contemporary international law, although formally established through and for states, usually has major economic actors as its real addressees. Their differentiated status is increasingly recognised in international law, for example, in the context of investor-state dispute settlement mechanisms. An international law of corporate social responsibility could constitute the

68 Bethlehem, n. 6 above, p. 19.

69 Affolder, n. 32 above, pp. 456-460.

70 Richardson, n. 32 above, p. 327.

71 Ibid., pp. 332-337.

72 H. P. Nehl, Principles of Administrative Procedure in EC Law (1999, Hart Publishing), pp. 214.

73 Kuo, n. 35 above, pp. 857-858; 862; Ellen Vos, 'Making Informal International Law Accountable: Lessons from the EU' in Joost Pauwelyn, Ramses A. Wessel \& Jan Wouters (eds), Informal International Lawmaking (2012, OUP), pp. 369-381. 
'differentiated responsibility pillar' to match the differentiated position and access that major economic actors increasingly enjoy in the international legal sphere.

Along similar lines, Bethlehem suggests a 'lex congregatio' or 'law of society'. In a preliminary attempt to operationalise this model, he proposes the following features:

first, an instrument of traditional inter-state law that would act as a platform on which would stand a second tier set of protocols and principles addressing the application and mutual recognition of rules and standards relevant to particular conduct; thirdly, a further tier of industry-driven and derived minimum standards of conduct; and all this finally held together by a basic principle that actors are bound by what they accept — whether by their conduct, by the click of a mouse button on an "I agree" icon on a software program, or in some other manner. ${ }^{74}$

\subsubsection{Reconstructing Law: Strengths and Weaknesses}

The strongest appeal of defensive and adaptive responses is that they acknowledge the disruptive impacts of transnationalisation head-on, and seek to mend the fissures between the idea of law and law in practice through enduring, sustainable solutions. These solutions, which usually consist of the introduction of new layers of public law to govern transnational action and clarify the status of transnational regulatory decisions, enable law to regain a sense of locality, exclusivity in authorship, disciplinary clarity, constitutional and regulatory functionality, and comprehensiveness. They recast the net in order better to cover the richness and variety of transnational regulatory activity, which helps to restore the concept of law in its traditional splendour.

Less felicitously, the reconstruction of law engenders an extensive degree of juridification in an already heavily legalised world. Moreover, it begs the question by whose authority any new layers of law to govern transnational activity could legitimately be adopted. The dilemma is neatly illustrated in a discussion by Thoko Kaime and Robert Glicksman on the vulnerability of eco-system markets to underperformance, abuse and fraud. The authors trace the problem partly to a dearth of accountability requirements in ecosystem contracting, and propose the following solution:

We believe that the foundation of a reliable market that is capable of achieving efficient and effective protection of ecosystem services must rest on five pillars of accountability: (i) financial safeguards, (ii) verifiable performance standards, (iii) transparency and public participation standards, (iv) regulatory oversight mechanisms, and (v) rule of law safeguards. We derive these standards from three sources. Firstly, these accountability tools emerge from identification of

\footnotetext{
74 Bethlehem, n. 6 above, p. 24.
} 
the flaws we believe are responsible for the abuses of market-based approaches to environmental protection discussed above. Secondly, we draw on experience from market-based programmes which appear to have worked well or which include mechanisms that promise to effectively curb abuses of environmental markets, such as the US CAA acid rain programme and the CWA wetlands protection programme. Thirdly, we rely on important principles of international law, such as the obligations to provide transparency and opportunities for public participation imposed by the Aarhus Convention. ${ }^{75}$

Kaime and Glicksman's care in justifying the basis for their selection of five accountability standards underscores the essentially precarious nature of the exercise. In the absence of a transnational legislature, the borders between proposing and imposing legal order are ill-defined. When all is said and done, Kaime and Glicksman's list of accountability standards remains the fruit of their selection process; it has credibility because the authors are legal professionals and experts, but this is not the kind of credibility that is typically considered sufficient to justify acts of law making.

Proposals for the reconstruction of law at the transnational level must confront the uneasy reality that they are, in essence, undemocratically formulated responses to problems that are, themselves, in no small measure a consequence of the dissolution between regulation and democratic oversight in the transnational sphere. ${ }^{76}$ The EU legal regime, we recall, faces unrelenting 'democratic deficit' allegations, in spite of having incorporated over the years a veritable arsenal of checks and balances, institutional innovations and decision making mechanisms in a continuing quest to boost the democratic credibility of its legislative and regulatory output. The EU experience serves as a cautionary reminder that the mission of reconstructing law at the transnational level to govern transnational regulatory activity will inevitably be fraught with political controversy and ongoing challenges to the authority of the transnational legal regime.

\subsection{Creative and Adaptive: Reconceptualising LaW}

Whether a fringe event or a development that affects vast swathes of the legal system, the transnationalisation of law presents a problem that needs to be managed. That is the view shared by those who seek to reclaim or reconstruct law. The implicit assumption from which both lines of thought depart, is that the traditional understanding of law as territorial, emanating from the state, organised in public and private domains, functionally constitutive, regulating and structurally comprehensive, is a notion worth protecting and preserving. However, what if we relinquish the idea that law is and must always remain defined by these traditional

\footnotetext{
75 Glicksman \& Kaime, n. 21 above, p. 271.

${ }^{76}$ Cf A. Somek, 'Constituent Power in National and Transnational Contexts' (2012) 3(1) Transnational Legal Theory, pp. 31-60.
} 
attributes, and instead embrace the possibility of the metamorphosis of law into a ubiquitous, pluralistic, fragmented and reflexive phenomenon? Or, what if we start from an alternative assumption, namely, that the traditional attributes of law have always been mythical? Arguably, law has never really lived up to its territorial, statebased and comprehensive billing. ${ }^{77}$ If that is the case, then the rise of transnational regulation has not transformed the nature of law but instead tipped the veil on the artificiality of the incumbent paradigm. ${ }^{78}$

The latter perspectives are likely to elicit adaptive and creative responses that seek not to restore but instead to reconceptualise law. ${ }^{79}$ The transnationalisation of law is not so much a disruption to be managed as it is an opportunity to further our knowledge about law's nature and dynamics; to adapt the cognitive frameworks through which legal processes are perceived and constructed, and to develop a paradigm that is better attuned to the new (or newly revealed) reality of law. In this context, transnational law is no longer a shorthand for law that does not fit the within mainstream paradigm, but becomes the denominator of an alternative account of law that 'methodologically responds to the fragmented, embedded evolutionary dynamics of norm creation in the context of world society'. ${ }^{80}$

The reconceptualisation of law necessitates the development of new tools to organise and structure our thinking about law; tools that are not reliant on conventional tropes (e.g., sovereignty, jurisdiction), dividing lines (e.g., the public/private divide) and decisionistic mechanisms (primacy). The creative effort of rethinking law in a mode that is less beholden to its conventional attributes echoes the intellectual challenges experienced in the quest for a de-institutionalised, de-centred concept of regulation. As in that case, it is difficult to break free from the shackles of conventional thinking; we all too easily equip new models with thinly disguised re-workings of old formulae. In a second parallel with the reconceptualisation of regulation, the development of a paradigm of transnational law is very much work in progress. The paragraphs below introduce some of the key exponents of the process so far.

\subsubsection{The Organisation of Transnational Law}

A first prominent feature in transnationalisation scholarship is the demarcation of nascent legal spheres that are neither territorially defined nor clearly reducible to the public or private sphere. Attempts to chart domains of law that are united by characteristics other than their shared geography or location in the public or private field, respond to our abiding need for boundaries to structure legal thought and action. The existence of disciplinary boundaries facilitates the performance of a number of essential operations including, to name but a few, the framing and

\footnotetext{
77 Ladeur, n. 4 above, p. 5.

78 Brütsch \& Lehmkuhl, n. 17 above, 23.

79 Zumbansen, n. 5 above, p. 133.

80 Ibid.
} 
scoping of legal conflicts; the selection of relevant bodies of legislation, case law and literature for the purpose of research and argumentation; and the identification of fields of professional expertise. The waning relevance of territorial boundaries and public/private divides is therefore as disorienting as it is liberating, and fuels a demand for new categorisations and criteria to organise the vast expanse of law into manageable segments.

The quest for functional equivalents to territorial and traditional disciplinary divides may well explain why the lex mercatoria, for instance, is experiencing something of a revival in today's legal scholarship. In contemporary writing, it is frequently held up as a model for transnational law that has an autonomous identity and an internal logic without being territorially confined or anchored to a predetermined source of legal authority. ${ }^{81}$ It serves as both a structural and, evidently, linguistic inspiration for the denomination of new transnational fields such as the lex digitalis, which refers to the burgeoning body of principles, conventions and rules that structure the online environment, and the lex sportiva, which fulfil a parallel function for sports. ${ }^{82}$

The identification of delocalised fields of law may be accompanied by proposals to align emerging legal frameworks along traditional formats, which imbue the discussion with a reconstructive lean. Yet others eschew the traditional trappings of legality and are geared towards the analytical exercise of uncovering transnational law as they find it. Compare, for example, Bethlehem's aforementioned proposal for a lex congregatio with von Benda-Beckmann's discussion of 'project law'. The former derives its legal status from 'an instrument of traditional inter-state law that would act as a platform'. ${ }^{83}$ 'Project law,' in contrast, refers to an organically evolving body of principles, rules and procedures made and replicated by transnationally operating funding agencies and development projects. It is a flexible category that may expand to include stipulations determined by law and political conditions of the donor country, but its identity as project law and its internal organisation are not dependent on the involvement of state law. ${ }^{84}$

The turn towards delocalised fields of law that are neither public nor private, has important institutional ramifications. The dissolution of clear public/private distinctions between actors connected to a transnational project or linked via commercial practices, digital networks or sporting events, creates scope for access on equal terms to institutional resources such as review processes and dispute settlement mechanisms. The multiplication of legal authorship may thus constitute the basis for an expansion of external accountability. Thus far, the cracks in the

81 E.g., Gunther Teubner, 'The Project of Constitutional Sociology: Irritating Nation State Constitutionalism' (2013) 4(1) Transnational Legal Theory pp. 44-58 at 49; Klaus Peter Berger, The Creeping Codification of the New Lex Mercatoria (2nd ed., 2010, Center for Transnational Law); Alec Stone Sweet, 'The New Lex Mercatoria and Transnational Governance' (2006) 13(5) Journal of European Public Policy, pp. 627646.

82 Ladeur, n. 4 above, p. 10.

83 n. 74 above.

${ }^{84} \mathrm{~F}$. von Benda-Beckmann and K. von Benda-Beckmann, 'The Dynamics of Change and Continuity in Plural Legal Orders', (2006) 53-4 Journal of Legal Pluralism \& Unofficial Law p. 19 
institutional wall between the public and private spheres have mostly favoured large transnational firms, granting them privileged standing in claims vis-à-vis state bodies, most controversially so in litigation on the basis of investment treaty provisions. ${ }^{85}$ However, a fuller reconceptualisation of law in the transnational context might open the door towards a finer calibration of actor's rights and responsibilities that is no longer determined by their public or private status, and that instead takes its cue from their relative position in the commercial/digital/project/sporting network.

\subsubsection{The Plurality of Transnational Law}

A pressing agenda point for advocates of reconceptualisation, is to devise productive solutions to the loss of hierarchy as an ordering mechanism and a problem solving technique. The sources of transnational law are understood as plural, heterarchical, and theoretically infinite: there is no pre-ordained limit on the range of actors that engage in transnational norm-generating behaviour. ${ }^{86}$ Moreover, no single institution - whether state, intergovernmental organisation or association of large commercial enterprises - can credibly lay claim to the exclusive competence to recognise and validate the creation of transnational law. Transnational law can thrive in the absence of a discernible Grundnorm and beyond the control of a designated authority equipped to sanction and rank its normative communications. The rise of transnational law thus creates a double bind: it generates new layers of normativity, which increases the likelihood that situations will be governed by multiple, potentially conflicting bodies of law. Yet it simultaneously strips law of its most effective decision making technique, namely, resolving conflict through determinations of primacy, made by institutions that have been constitutionally empowered to that effect.

The most obvious way of dealing with the plurality of law is, simply, to bear it. That is, to resist he urge to stratify spheres of legality and to tolerate accompanying incommensurabilities in legal decision making as the inevitable side-effect of high levels of diversified legal productivity. One of the most developed exponents of this approach can be found in Nico Krisch's postnational, radical pluralism. Radical pluralism embodies an appealingly optimistic disposition: it expresses faith in the resilience of legal structures; they can bear a quantity of dissonance without descending into chaos. ${ }^{87}$ Moreover, Krisch argues that it is important not to overstate the degree of conflict that legal pluralism will elicit: for all its diversity, there are strong similarities and overlaps in our normative heritage that influence legal decision making within and outside conventional legal regimes. Finally, an absence of hierarchy does not necessarily equate an unwillingness to take inspiration

${ }^{85}$ Cf. J. Kleinheisterkamp, 'Financial Responsibility in European International Investment Policy,' (2014)

63:2 International \& Comparative Law Quarterly 449-476.

${ }^{86}$ Thornhill, n. 13 above, pp. 398-9.

87 N. Krisch, 'Who's Afraid of Radical Pluralism' (2011) 24(4) Ratio Juris, pp. 386-412, at 397-400. 
from others. Plurality leaves scope for informal coordination, which could potentially reap more stable results than hierarchically imposed assimilation.

\subsubsection{The Functions and Structure of Transnational Law}

Creative and adaptive responses to transnationalisation are less preoccupied with restoring law's waning constitutive and disciplining force vis-à-vis transnational environmental regulation, and more with harnessing the reflexive and communicative strengths of law. In this vein, one of transnational law's chief functions is to enable the 'peaceful co-existence' of heterarchical normative regimes. Importantly, transnational law does so not by exogenously imposing a superstructure of constitutional and administrative prescriptions to which transnational regimes must be subjected, but through the introduction of interstitial norms ${ }^{88}$ that serve to coordinate, orchestrate and moderate. ${ }^{89}$ The emphasis on the liaising, facilitating functions of law has a profound structural impact. Under a creative, adaptive conceptualisation of transnational law, the norms that govern transnational regulatory behaviour are not created outside the regulatory context but are better understood as composite co-products of the very practice of transnational regulation..$^{90}$ They are not situated above but in-between an indeterminate and changing number of regulatory regimes, their content and status constantly evolving through processes of regulatory application and feedback.

\subsubsection{Reconceptualising Law: Strengths and Weaknesses}

Creative and adaptive responses to transnationalisation exercise a powerful draw on the legal imagination. Although less familiar, the idea of organically co-produced norms that emerge from the very behaviour that they seek to govern, arguably rings truer to experience than the sterile representation of law and action as essentially separate spheres. ${ }^{91}$ In this vein, Zumbansen comments on the concreteness, the earthiness of legal pluralism: 'Legal pluralists, by drawing on anthropological and sociological accounts to more adequately capture the dynamics of norm-creation and regulatory practice, scrutinize the distinction between a legal and a social norm to better understand the concrete process through which a norm comes into existence and is adhered to or rejected'. ${ }^{92}$

The lure of reconceptualising law seems to grow even stronger when contrasted with the repressive inclination of attempts to reclaim law. The former's willingness to acknowledge 'norms that do not fit' throws into sharp relief the tendency of defensive and conservative responses to ignore or define them out of existence.

88 Cf. V. Barral, 'Sustainable Development in International Law: Nature and Operation of an Evolutive Legal Norm' (2012) 23(2) European Journal of International Law, pp. 377-400, at 388-390.

89 O. Dilling, 'Legitimacy Collisions in 3D: Some Queries with the Third Dimension of Joerges' Conflicts Law' in C. Joerges \& T. Ralli (eds) After Globalisation: New Patterns of Conflict and their Sociological and Legal Reconstructions (Oslo, RECON Report series 2011), p. 8.

${ }^{90}$ Ladeur, n. 4 above, p. 5.

${ }^{91}$ Berman, n. 51 above, p. 11.

92 Zumbansen, n. 5 above, p. 133. 
Such responses may bring short-term relief, but they are hardly sustainable attempts at problem solving.

The reconceptualisation of law along more heterarchical, pluralistic and reflective lines could also be preferable to conservative and adaptive (reconstructive) approaches. Pragmatically speaking, reconceptualisation may be more attainable than the large-scale legislative efforts that would be required to replicate the conventional structure, organisation and functions of law at the transnational level. If developments in international environmental law over the past 20 years are an indication, there is currently a limited appetite for the kind of grand legislative orchestration that would be needed to develop a coherent, overarching transnational legal framework. The universalistic spirit of the 1992 United Nations Framework Convention on Climate Change (UNFCCC) ${ }^{93}$ and the Convention on Biological Diversity (CBD), ${ }^{94}$ it transpires, did not set the mould for the future of environmental agreements, but instead contrasts with the more recent practice of international environmental lawmaking which, when it is not amending Protocols and Annexes to older treaties, tends to be either regional and/or narrowly sectoral in nature. ${ }^{95}$ The only arguable exception to the narrowing remit of international agreements is the Aarhus Convention on Access to Environmental Information, Public Participation in Decision Making and Access to Justice, which is now nearly 20 years old and is, in fact, regional rather than global in scope.

Reconceptualisation and reconstruction also represent starkly different political choices, neither of them unproblematic. To many, the advanced juridification that accompanies reconstructive approaches, and the extent to which they concentrate decision making power in the hands of a global, politically unaccountable elite, are deeply unsettling. ${ }^{96}$ The pluralism of creative and adaptive responses to transnationalisation could offer an antidote to the development of a winner-decidesall society. ${ }^{97}$ The absence of a supreme body of law, interpreted by a privileged set of transnational institutions, is a welcome reminder of the virtues of opposition and contestability. Moreover, as Krisch observes with regard to contestation, in instances where legal regimes collide, there is no reason to assume that law is better equipped than politics to resolve the ensuing tensions. ${ }^{98}$

However, the pluralistic model, too, poses significant political risks. Pluralism may result in a greater diffusion of power than attempts to reconstruct law at the transnational level, but it is equally vulnerably to the democratic deficit critique. ${ }^{99}$

\footnotetext{
93 New York, NY (US), 9 May 1992, in force 21 Mar. 1994, available at: http://unfccc.int.

94 Rio de Janeiro (Brazil), 5 June 1992, in force 29 Dec. 1993, available at: http://www.cbd.int/convention/text.

95 For a comprehensive overview of international environmental law-making activity through time, see the International Environmental Agreements Database Project at http://iea.uoregon.edu/page.php?query= summary\&type=MEA.

96 Berman, n. 51 above, p. 10.

97 T. C. Halliday \& G. Shaffer (eds) Transnational Legal Orders (2015, CUP), p. 27.

98 N. Krisch, Beyond Constitutionalism. The Pluralist Structure of Postnational Law (2010, OUP), p. 283.

99 I am grateful to Greg Shaffer for this observation.
} 
The lex mercatoria, for example, is hardly the law of the people; it is made by and arguably in support of a global commercial elite with expert transactional knowledge, yet its reach extends far beyond its authors. ${ }^{100}$

Secondly, an open acknowledgement of legal pluralism may erode law's legitimizing function. Since the connection between TER and democratic representation is both weak and remote, the legitimacy of transnational regulators is strongly beholden to alternative claims to authority. These are typically partially based on qualities such as expertise and output efficiency, but they are also significantly furthered by the perception that the transnational actor under scrutiny is accountable and respects the rule of law. Legal pluralism might both limit the availability and robustness of accountability mechanisms, and erode the universal significance of the concept of the rule of law, thus diluting the alternative bases upon which transnational actors can justify the power they wield. Unless backed up by additional guarantees, diffusion is a very thin basis on which to legitimate the exercise of otherwise unchecked legislative power.

Thirdly, Krisch's analysis, although impressively expansive, does not take into account what might be labelled as the 'more advanced' forms of transnational law, namely, the norms generated by private, hybrid or networked regulators outside the auspices of an international legal regime established with the fiat of participating states. Marty-Delmas' work on Ordering Pluralism, too, stays within the confines of highly institutionalised legal orders such as the UN treaty regime, the WTO, the ECHR and the EU.101 Whether the legal system possesses sufficient resilience to also productively respond to the normativity generated through private, hybrid and informal regulatory networks, remains untested.

A final weakness is that, although creative responses may be grounded in a more contextualised and resonant understanding of processes of norm-creation than conservative ones, their very analytical richness can simultaneously stunt their normative potential. Like spontaneity, plurality is difficult to engineer. It is in the formulation of reform proposals that advocates of pluralism are most prone to fall back on conventional tropes. The above-mentioned 'interstitial norms,' ${ }^{102}$ which should serve to coordinate between heterarchical normative spheres, exemplify the slippery slope between coordination and juridifcation and, thus, between reconceptualisation and reconstruction. In Delmas-Marty's work, for example, the assertion is made that legal pluralism should in the first place be organised through practices of cross-referencing. ${ }^{103} \mathrm{It}$ is an elegant solution to the decisionistic void at the heart of legal pluralism, and there is widespread evidence of this practice in transnational regulatory and judicial decision making. ${ }^{104}$ However, the suggestion does inevitably beg the question whether the requirement to cross-reference then

${ }^{100}$ Cf T. Schultz, Transnational Legality. Stateless Law and International Arbitration (2014, OUP), pp. 12-14.

101 M. Delmas-Marty, Ordering Pluralism. A Conceptual Framework. for Understanding the Transnational Legal World (2009, Hart Publishing) (translated by Naomi Norberg).

102 n. 88 above.

103 Delmas-Marty, n. 101 above, pp. 19-37.

104 Ibid. 
becomes, itself, the hierarchically superior norm with which the plurality of legal regimes must conform and, thus, carries within itself the seeds to undermine the pluralistic vision. ${ }^{105}$

\section{CONCLUDING REMARKS}

It makes intuitive sense that the emergence of new spheres of transnational and often informal authority would challenge conventional understandings of law. The contribution of this paper was to pinpoint with greater precision where the impacts are being felt. To this end, the analysis identified five key pressure points, namely, conceptualisations of the location, source, organisation, functions and structure of law. For each of these attributes, the expansion of transnational governance regimes, such as those aimed at transnational environmental regulation, provokes a problematisation of long held assumptions about what law is and how it works.

Beyond mapping out the breadth of transformations that, together, constitute the transnationalisation of law, the discussion conveyed a number of significant messages regarding the relation between TER and law. Not every variant of transnational regulation is equally challenging to mainstream conceptualisations of law. Unsurprisingly, regulatory initiatives that flourish under the auspices of wellestablished frameworks of international or regional law, with EU regulation as a prime example, pose less acute conceptual challenges than transnational private and hybrid regulatory networks, which may display an evolving composition and exert fluctuating levels of authority. However, the discussion equally confirmed that, if the presence of a mature regime such as EU environmental regulation is superficially reconcilable with the traditional conceptualisation of law, dissonances remain. The EU legal regime may offer rough functional equivalents to the assumptions of territoriality, exclusivity, exhaustiveness and cohesion that support traditional understandings of legality, but closer inspection quickly reveals their frailty. Even the densely institutionalised, highly organised landscape of EU law cannot fully camouflage the gaps and fissures caused by the evolution of transnational regulatory authority.

A key message that resonates from the overview of possible reactions to the transnationalisation of law, is that seemingly 'commonsensical' proposals for the classification of new forms of environmental regulation, or for the extension or introduction of new rules and principles to govern them, represent important choices that are not only conceptual but also deeply political in nature. The term

105 Similarly, in what Van Asselt calls a 'constitutional twist', Krisch cannot resist the siren call of 'interface norms' that reintroduce a degree of layering or informal hierarchy into the system of law. See H. Van Asselt, 'Pluralism, Informality and Transnational Environmental Law' (2014) 3(1) Transnational Environmental Law, pp. 173-189, at 179 . 
'soft law' has become so ubiquitous that its use is hardly questioned. Yet it is important to remember that its deployment implies a clear choice to maintain a hierarchy between traditional and alternative sources of authority. In a similar vein, the frequently voiced opinion that TER is likely to suffer from deficiencies in transparency and accountability which should be overcome through the imposition of good governance standards borrowed from the wellsprings of national administrative law, is not 'simply' a sound suggestion to respond to perceived legitimacy deficits, but also represents a decision to centralise legislative authority; a decision with serious democratic and distributive consequences. Conversely, the approach to reconceptualise law as pluralistic, polycentric and reflexive may result in an alternative distribution of authority, but it is equally political and contentious. The aim of the exploration in this paper was not to elevate one of the three identified responses as superior, but to drive home the point that none of these choices are innocent. 